\title{
Protective Effects of Agmatine against Chlorpromazine- Induced Toxicity in the Liver of Wistar Rats
}

\author{
Bratislav Dejanović ${ }^{\text {, Ivana Stevanović }}{ }^{2}$, Milica Ninković ${ }^{2}$ \\ Ivana Stojanović3 ${ }^{3}$ Irena Lavrnja ${ }^{4}$, Tatjana Radičević ${ }^{5}$ \\ ${ }^{1}$ Military Medical Center "Karaburma", Belgrade, Serbia \\ ${ }^{2}$ Institute for Medical Research, Military Medical Academy, Belgrade, Serbia \\ ${ }^{3}$ University of Nis, Faculty of Medicine, Institute for biochemistry, Nis, Serbia \\ "Institute for Biological Research "Sinisa Stankovic", Belgrade, Serbia \\ Institute of Meat Hygiene and Technology, Belgrade, Serbia
}

SUMMARY

The metabolic pathways of chlorpromazine (CPZ) toxicity were tracked by assessing oxidative/nitrosative stress markers. The main objective of the study was to test the hypothesis that agmatine (AGM) prevents oxidative/nitrosative stress in the liver of Wistar rats 15 days after administration of CPZ. All tested substances were administered intraperitoneally (i.p.) for 15 consecutive days. The rats were divided into four groups: the control group $(C, 0.9 \%$ saline solution), the CPZ group (CPZ, $38.7 \mathrm{mg} / \mathrm{kg}$ b.w.), the CPZ+AGM group (AGM, $75 \mathrm{mg} / \mathrm{kg} \mathrm{b.w}$. immediately after CPZ, $38.7 \mathrm{mg} / \mathrm{kg}$ b.w. i.p.) and the AGM group (AGM, $75 \mathrm{mg} / \mathrm{kg} \mathrm{b.w.).}$

Rats were decapitated 15 days after the appropriate treatment. In the $\mathrm{CPZ}$ group, $\mathrm{CPZ}$ concentration was significantly increased compared to $C$ values $(p<0.01)$, while $A G M$ treatment induced the significant decrease in CPZ concentration in the CPZ+AGM group $(p<0.05)$ and the AGM group $(\mathrm{p}<0.01)$. CPZ application to healthy rats did not lead to any changes of lipid peroxidation in the liver compared to the $C$ group, but AGM treatment decreased that parameter compared to the CPZ group ( $\mathrm{p}<0.05$ ). In $\mathrm{CPZ}$ liver homogenates, nitrite and nitrate concentrations were increased compared to controls $(\mathrm{p}<0.001)$, and AGM treatment diminished that parameter in the CPZ group ( $\mathrm{p}<0.05$ ), as well as in the AGM group ( $<<0.001)$. In CPZ animals, glutathione level and catalase activity were decreased in comparison with $C$ values $(p<0.01$ respectively), but AGM treatment increased the activity of catalase in comparison with $\mathrm{CPZ}$ animals ( $<<0.05$ respectively). Western blot analysis supported biochemical findings in all groups. Our results showed that treatment with AGM significantly supressed the oxidative/nitrosative stress parameters and restored antioxidant defense in rat liver.

Key words: agmatine, antioxidant defense, chlorpromazine, liver, oxidative stress

Corresponding author:

Bratislav Dejanovic

e-mail: bracadejanovic@yahoo.com 


\section{INTRODUCTION}

Oxidative and nitrosative stress are involved in the pathophysiology of various neurological disorders. Chronic treatment with neuroleptics increases the production of free radicals and the development of oxidative stress (OS) (1). Typical antipsychotics lead to increased OS by altering the levels of antioxidant enzymes, and cause oxidative damage, particularly lipid peroxidation (LPO) in the brain (2).

Chlorpromazine (CPZ) is a typical antipsychotic that may cause distressing side effects involving the extrapyramidal tract (3). The mechanism of CPZinduced liver injury has been proposed, but has not been fully clarified, since many factors were found to be implicated in its adverse effects on the liver. CPZ leads to a dose-related impairment in bile secretion and changing hepatocyte and canalicular membrane fluidity, which consequently affects the functional integrity of these sites. It has been shown that oral administration of CPZ for two weeks causes infiltration of inflammatory cells and leads to focal necrosis (4).

The mechanism responsible for CPZ-induced injury includes damage initiated by the activation of Kupffer cells, which release proinflammatory cytokines and stimulate the migration and accumulation of neutrophils and monocytes in the liver. Activated inflammatory cells amplificate primary injury induced by CPZ (5).

It is known that neuroleptics increase free radical production and development of OS (1). Tiobarbituric acid reactive supstances (TBARS) are markers of LPO and were significantly increased after CPZ poisoning (6)

The induction of LPO may be a major factor in oxidative- and nitrosative-mediated liver damage (7).

Nitric oxide (NO) is the product of a fiveelectron oxidation of the amino acid L-arginine. It can produce hydroxyl radicals $(\mathrm{OH} \bullet)$ as well as nitrogen dioxide radical (8). Nitric oxide is produced by the action of the isoenzymes of NO synthases (NOS). It may react with thiol groups in amino acids and proteins and form relatively stable nitroso-thiols (9). Also, NO can be coupled with superoxide anion radical $\left(\mathrm{O}_{2}{ }^{-}\right)$to produce peroxynitrite (ONOO-), a harmful compound to cellular structures, which has been linked to several interactions that may contribute to cellular damage, including LPO (10).

Under physiological conditions, the potential for free radical-mediated damage is kept in check by the antioxidant defense system, which is composed of enzymatic and non-enzymatic components (2). Our previous study showed that CPZ increased the production of free radicals and affected the antioxidant enzyme activity in rat liver (11). It is known that OS in the liver is a consequence of increased production of free radicals and decreased capacity of antioxidant defense systems in hepatocytes (12).

The present study was directed to potentially benefit the influence of agmatine (AGM) on oxidative stress development during CPZ toxicity. The liver plays a crucial physiological role in the maintenance of AGM homeostasis $(13,14)$. Studies have shown that AGM may serve as a novel therapeutic strategy for hepatic inflammatory diseases $(15,16)$. Contrary, biochemical analysis in experimental rats revealed that CPZ treatment significantly induced LPO and decreased glutathione (GSH) levels, as well as antioxidant defense enzymes superoxide dismutase (SOD) and catalase (CAT) (3). Based on these findings, the main objective of our research was to investigate the role of reactive oxygen (ROS) and nitrogen (RNS) species, as well as the efficiency of antioxidant protection in rat liver in subacute CPZ intoxication after AGM treatment.

\section{MATERIAL AND METHODS}

\section{Animals}

The experimental animals were treated according to the Guidelines for Animal Study, No. 282-12/2002 (Ethics Committee of the Military Medical Academy, Belgrade, Serbia and Montenegro).

Male adult Wistar rats, 2 months old, with body mass $200 \pm 50 \mathrm{~g}$, were used for the experiment. Groups of two or three rats per cage (Erath, FRG), were housed in an air conditioned room at the temperature of $23 \pm 2{ }^{\circ} \mathrm{C}$ with $55 \pm 10 \%$ humidity and with lights on $12 \mathrm{~h} /$ day (07.00-19.00 h). The animals were given a commercial rat diet and tap water ad libitum.

\section{Experimental procedure}

The experiment was accomplished with the following (four) experimental groups, which received different testing substances: the control group $(\mathrm{C}, 0.9$ $\%$ saline solution), $\mathrm{n}=10$; the $\mathrm{CPZ}$ group (CPZ- $\mathrm{HCl}$ $38.7 \mathrm{mg} / \mathrm{kg}$ b.w.), $\mathrm{n}=10$; the CPZ+AGM group (AGM, $75 \mathrm{mg} / \mathrm{kg}$ b.w. i.p., immediately after CPZ-HCl 
administration, $38.7 \mathrm{mg} / \mathrm{kg}$ b.w.), $\mathrm{n}=10$; and the AGM group (AGM, $75 \mathrm{mg} / \mathrm{kg}$ b.w. i.p.), $\mathrm{n}=10$. The animals were sacrificed by decapitation 15 days after the treatments. For the same purpose, the liver were excised and stored at $-20^{\circ} \mathrm{C}$.

\section{Determination of CPZ concentration}

The concentration of $\mathrm{CPZ}$ was determined in the liver using a high performance liquid chromatography-tandem mass spectrometry (HPLC MS / MS) (17).

In one gram of liver tissue, $4 \mathrm{~mL}$ of acidic acetonitrile was added and the sample was homogenizated on Ultra Turax, then centrifuged for 10 minutes at $3500 \mathrm{rpm}$. After centrifugation the supernatant was decanted into clean tube and $6 \mathrm{~mL} 10$ $\% \mathrm{NaCl}$ solution were added to the supernatant. The purification was performed on C-18 columns, which were conditioned by passing of $5 \mathrm{~mL}$ of methanol, folowed by $5 \mathrm{~mL}$ of water. After the sample extract was loaded onto conditioned SPE colums and passed trough, SPE columns were washed with $1 \mathrm{~mL} 0.01$ mol $\mathrm{H}_{2} \mathrm{SO}_{4}$. CPZ was eluted from SPE colums with $2 \times 3 \mathrm{~mL}$ mixture of acidic acetonitrile and methanol (50:50), eluated then evaporated under the stream of nitrogen and the residue was dissolved in $1 \mathrm{~mL}$ of a mixture of acidic acetonitrile and methanol (50:50).

The method was performed on HPLC MS/MS Waters Acquity with TQD detector. The chromatographic conditions for HPLC MS/MS were as follows: guard column and a reversed phase column C-18; $2.1 \times 100 \mathrm{~mm}$; $3.5 \mu \mathrm{m}$; temperature 35 ${ }^{\circ} \mathrm{C}$, mobile phase A- $0.1 \% \mathrm{HCOOH}$ in water : Bmethanol. Gradient: 0 min - 5 min $95 \%$ A, 5 min - 6 $\min 30 \%$ A, $6 \min -7 \min 0 \%$ A, 7 min- $13 \min 95 \%$ A, a mobile phase flow rate was $0.4 \mathrm{~mL} / \mathrm{min}$. The mass detector in the positive ESI mode: protonated molecular ion: $\mathrm{m} / \mathrm{z} 319.3 \rightarrow 86.319,3 \rightarrow 245.9$ for CPZ. The voltage on the capillaries was $3.5 \mathrm{kV}$. Cone voltage $35 \mathrm{~V}$.

The stock standard solution of $\mathrm{CPZ}$ was prepared in methanol (concentration $0.897 \mathrm{mg} / \mathrm{mL}$ ) and standard working solutions were prepared by diluting the stock standard solution in mobile phase.

\section{Measurement of oxidative/nitrosative status parameters}

The liver tissue was dissected on ice, and slices of the liver tissue were transferred separately into cold buffered sucrose $(0.25 \mathrm{~mol} / \mathrm{L}$ sucrose, $0.1 \mathrm{mmol} / \mathrm{L}$ EDTA in $50 \mathrm{mM}$ sodium-potassium phosphate buffer, $\mathrm{pH}$ 7.2). Homogenization of the tissue in the sucrose medium was performed by a homogenizer with a Teflon pestle at $800 \mathrm{rpm}$ for 15 minutes at $4{ }^{\circ} \mathrm{C}$. The supernatant was centrifuged at $2500 \mathrm{~g}$ for 30 minutes at $4{ }^{\circ} \mathrm{C}$. The resulting precipitate was suspended in 1.5 $\mathrm{mL}$ of deionised water. Homogenates were centrifuged at $2000 \mathrm{~g}$ for 15 minutes at $4{ }^{\circ} \mathrm{C}$ and the resulting supernatant was used for analysis (18). Total protein concentration was estimated with bovine serum albumin as a standard (19).

Lipid peroxidation in forebrain cortex was measured as tiobarbituric acid reactive substances production (TBARS), as described by Girotti et al. (20). Data were expressed as nmol per $\mathrm{mg}$ of proteins.

After deproteinization, the production of $\mathrm{NO}$ was evaluated by measuring nitrite and nitrate concentrations $\left(\mathrm{NO}_{2}+\mathrm{NO}_{3}\right)$. Nitrates were previously transformed into nitrites by cadmium reduction (21). Nitrites were assayed directly spectrophotometrically at $492 \mathrm{~nm}$, using the colorimetric method of Griess (Griess reagent: $1.5 \%$ sulfanilamide in $1 \mathrm{~mol} \mathrm{HCl}$ plus $0.15 \% \quad \mathrm{~N}$-(1-naphthyl) ethylendiamine dihydrochloride in distilled water). The results were expressed as nmol per $\mathrm{mg}$ of proteins.

Total glutathione (GSH+1/2GSSG, in GSH equivalents) content was determined with DTNBGSSG reductase recycling assay. The rate of formation of 5-thio-2-nitrobenzoic acid (TNB), which is proportional to the total GSH concentration, was followed spectrophotometrically at $412 \mathrm{~nm}$ (22). The results were expressed as nmol per mg of proteins.

Catalase activity was determined by spectrophotometric method. Ammonium molybdate forms a yellow complex with $\mathrm{H}_{2} \mathrm{O}_{2}$ and is suitable for measuring both serum and CAT activity in the tissue (23). Kinetic analysis was performed at $405 \mathrm{~nm}$. Units of CAT activity is defined as the number micromol $\mathrm{H}_{2} \mathrm{O}_{2}$ reduced per minute $\left(\mu \mathrm{mol} \mathrm{H}_{2} \mathrm{O}_{2} / \mathrm{min}\right)$. Data were expressed as U CAT per mg of proteins.

\section{Reagents}

All chemicals used in this study were of analytical grade. DTNB, $\mathrm{NaH}_{2} \mathrm{PO}_{4}$, ammonium molybdate, NADPH and NADH were purchased from Merck (Darmstadt, Germany). $\mathrm{Na}_{2} \mathrm{HPO}_{4} \mathrm{x}$ $2 \mathrm{H}_{2} \mathrm{O}$, TCA, methanol and GSSG (oxidized form) were purchased from Serva, Feinbiochemica GmbH \& Co Heidelberg, New York. TBA was purchased from 
ICN Biomedicals Inc., Ohio, and acetonitrile was purchased from Backer J.T., Deventer, Netherlands. Glutathione reductase (EC 1.6.4.2), Type III, from yeast [9001-48-3], Sigma Chemical Co (St Luis, MO, USA) - highly refined suspension in $3.6 \mathrm{M}\left(\mathrm{NH}_{4}\right)_{2} \mathrm{SO}_{4}$, at $\mathrm{pH} 7.0 ; 2500 \mathrm{U} / 1.6 \mathrm{~mL}$ (9.2 $\mathrm{mg}$ prot $/ \mathrm{mL}$ - biuret) 170 $\mathrm{U} / \mathrm{mg}$ proteins (Note: 1 unit reduces $1 \mu \mathrm{mol}$ GSSG/min, pH 7.6 at $\left.25{ }^{\circ} \mathrm{C}\right)$. Sodium nitrate $\left(\mathrm{NaNO}_{3}\right)$ was purchased from Mallinckrodt Chemical Works St. Louis, MO, USA. Analytical standard for CPZ was purchased from Sigma-Aldrich Corporation, St. Louis, MO, USA; catalog number C8138, as well as sulphanilic acid and $\mathrm{N}$-(1-naphthyl)ethylendiamine dihydrochloride. Saline solution $(0.9 \% \mathrm{w} / \mathrm{v})$ was purchased by the Hospital Pharmacy (Military Medical Academy, Belgrade, Serbia). All solutions were made on the day when the experiments were done.

\section{Western blot analysis}

After decapitation, livers were dissected and pooled from three animals. The selected tissue was homogenized with a hand-held pestle in sodium dodecyl sulfate (SDS) sample buffer $(10 \mathrm{ml} / \mathrm{mg})$, which contained a cocktail of proteinase and phosphatase inhibitors (24). The electrophoresis samples were heated at $100{ }^{\circ} \mathrm{C}$ for 5 minutes and loaded onto $10 \%$ SDS-polyacrylamide gels with standard Laemmli solutions. The proteins were electroblotted onto a polyvinylidene difluoride membrane, which were placed in a blocking solution (Tris-buffered saline with $0.02 \%$ Tween TBS-T and 5 $\%$ non-fat dry milk) for 1 hour, and incubated overnight under gentle agitation with primary antibody mouse anti-ED1 (1:7000 Abcam, Cambridge, UK) and mouse anti- $\beta$-tubulin (1:1000; Sigma, St Louis, MO, USA). Bound primary antibodies were detected with a horseradish peroxidase (HRP)conjugated anti-mouse secondary antibody (1:5000; Santa Cruz Biotechnology, Santa Cruz, CA, USA). Immunoreactive bands were visualized on $\mathrm{X}$-ray films using chemiluminescence. Optical densities of immunoreactive bands from 4 independent blots were calculated in Image Quant program. The densities of ED1 and $\beta$-tubulin immunoreactive bands were quantified with background subtraction.
Squares of identical sizes were drawn around each band to measure density, and background near that band was subtracted. For each blot, optical densities were normalized against $\beta$-tubulin levels.

\section{Statistical analysis}

One Way ANOVA and Kolmogorov-Smirnov test were used (Software GraphPad Prism, version 5.01) for statistical data analysis. The data are presented as mean \pm SEM. The statistical significance of differences was determined by $\mathrm{p}<0.05$.

\section{RESULTS}

The results of our study found that CPZ treatment induced different changes in parameters of OS and antioxidant capacity in liver samples of experimental rats.

\section{$\mathrm{CPZ}$ concentration in the rat liver}

The concentration of $\mathrm{CPZ}$ was significantly increased in the liver of CPZ-treated animals compared to the controls (Table 1). The treatment with AGM alone or applied together with $\mathrm{CPZ}$ decreased $\mathrm{CPZ}$ concentration in the liver, compared to the $\mathrm{CPZ}$ group.

Table 1. CPZ concentration (ppm) in the rat liver 15 days after appropriate treatment

\begin{tabular}{lc}
\hline \hline & CPZ concentration \\
$\mathrm{C}$ & $1.30 \pm 0.60$ \\
$\mathrm{CPZ}$ & $4.70 \pm 1.79^{* *}$ \\
$\mathrm{CPZ}+\mathrm{AGM}$ & $2.40 \pm 1.11^{\#}$ \\
$\mathrm{AGM}$ & $1.35 \pm 0.91^{\# \#}$ \\
\hline \hline
\end{tabular}

\section{Concentrations of parameters of oxidative/nitrosative status in the rat liver}

The concentration of TBARS in the CPZ+AGM group was significantly decreased 15 days after the treatment in the liver, compared to CPZ-induced TBARS increase (compared to the control values) in the $\mathrm{CPZ}$ group of animals (Table 2). 
Table 2. Concentrations of parameters of oxidative/nitrosative stress - TBARS (nmol/mg proteins), $\mathrm{NO}_{2}+\mathrm{NO}_{3}$ (nmol/mg proteins) and antioxidative defense - GSH (nmol/mg proteins), CAT (U/mg proteins) in the liver of

Wistar rats

\begin{tabular}{|c|c|c|c|c|}
\hline & $\begin{array}{c}\text { TBARS } \\
\text { (nmol/mg proteins) }\end{array}$ & $\begin{array}{c}\mathrm{NO}_{2}+\mathrm{NO}_{3} \\
\text { (nmol/mg proteins) }\end{array}$ & $\begin{array}{c}\mathrm{GSH} \\
\text { (nmol/mg proteins) }\end{array}$ & $\begin{array}{c}\text { CAT } \\
\text { (U/mg proteins) }\end{array}$ \\
\hline C & $7.34 \pm 1.68$ & $12.00 \pm 1.15$ & $14.50 \pm 1.98$ & $84.10 \pm 4.21$ \\
\hline $\mathrm{CPZ}$ & $8.27 \pm 1.41$ & $20.78 \pm 2.60^{* * * *}$ & $9.73 \pm 1.12^{* *}$ & $70.90 \pm 6.88^{* *}$ \\
\hline $\mathrm{CPZ}+\mathrm{AGM}$ & $6.33 \pm 0.45^{\#}$ & $16.83 \pm 2.19^{* * *, \#}$ & $8.35 \pm 1.00^{* * * * \#, \#}$ & $79.68 \pm 5.62^{\#}$ \\
\hline AGM & $9.37 \pm 0.94$ & $12.35 \pm 2.02^{\# \# \#}$ & $18.18 \pm 2.68^{*, \# \# \# ~}$ & $84.83 \pm 11.16^{\#}$ \\
\hline
\end{tabular}

The administration of $\mathrm{CPZ}$ resulted in $\mathrm{NO}_{2}+\mathrm{NO}_{3}$ concentrations increase 15 days after the tretmant in the liver, compared to controls (Table 2). In the $\mathrm{CPZ}+\mathrm{AGM}$ and $\mathrm{AGM}$ group of animals, $\mathrm{NO}_{2}+\mathrm{NO}_{3}$ concentrations were decreased in the liver, compared to CPZ-treated group.

In the CPZ group, total GSH content was significantly decreased in the liver compared to the controls (Table 2). Total GSH content significantly decreased in the CPZ+AGM group compared to CPZ group in the liver 15 days after the treatment. Contrary, total GSH concentration increased in AGM group compared to both control and $\mathrm{CPZ}$ group in the liver (Table 2).

In the CPZ group, after 15 days, CAT activity was significantly lower in the liver, compared to the control (Table 2). However, CAT activity significantly increased in both $\mathrm{CPZ}+\mathrm{AGM}$ and AGM groups in the liver, compared to CPZ-treated animals 15 days after the treatment.

\section{Western blot analysis}

To assess the pattern of ED1 protein expression following CPZ-induced liver injury in rats and after AGM treatment, livers were isolated 15 days postinjury. Immunoblot analysis showed that ED1 was present as a single band with a molecular mass of about $37 \mathrm{kDa}$ (Figure 1). There was a significant increase in ED1 expression in physiological control compared to all other groups (CPZ, CPZ+AGM, AGM).
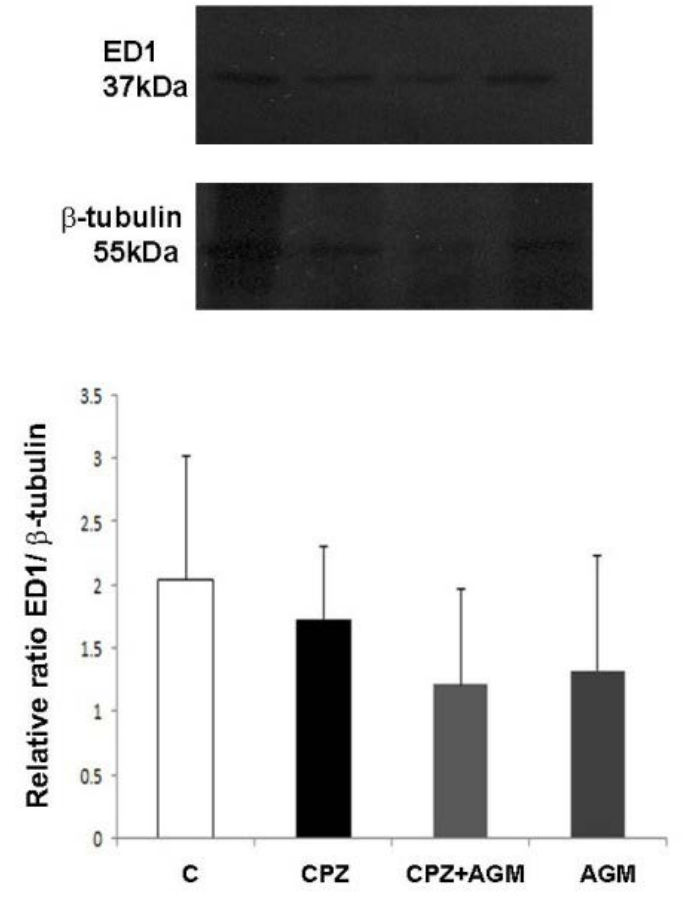

Figure 1. Quantitative immunoblot detection of ED1 protein levels in the liver isolated from control, CPZ, $C P Z+A G M$ and AGM group 15 days after the treatment. Bars represent mean ED1 protein abundance $( \pm$ SEM) from three independent determinations expressed relative to $\beta$-tubulin. Significance level is shown in the graph $\left({ }^{*} p<0.05 \mathrm{vs}\right.$. control), which is accompanied by a representative immunoblot. 


\section{DISCUSSION}

Presented results showed that OS played an important role in subacute CPZ-induced liver injury in rats, which can disturb the balance between ROS/RNS production and antioxidant defense in the liver.

In the rat liver, there was a greater increase in $\mathrm{CPZ}$ concentration compared to the brain. It confirms previous findings of the largest amount of deposited $\mathrm{CPZ}$ in the liver with the most important role for the manifestation of its harmful effects $(25,26)$. Subacute application of CPZ during 15 days induced the increase of concentration of the drug in rat liver compared with the control values (Table 1). However, the administration of $\mathrm{CPZ}+\mathrm{AGM}$ significantly decreased $\mathrm{CPZ}$ concentration in the liver, indicating that the presence of AGM reduced the deposition of CPZ.

Our research showed no significant change in the concentration of TBARS in the liver after CPZ administration (but a slight increase), while the combined treatment CPZ+AGM after 15 days significantly reduced the concentration of TBARS compared to the controls (Table 2). The liver has the greatest sensitivity to changes caused by $\mathrm{CPZ}$ and the reduction of TBARS by AGM may be the result of some induced mechanism of hepatoprotection (27).

It has been reported that low concentrations of AGM (10-100 mM) are able to amplify an OS pathway, which is triggered by the reaction products of AGM oxidation (28). However, if AGM is present at higher concentrations (e.g. 1-2 mM), it does not affect mitochondrial respiration and is ineffective in inducing OS (29).

Increased $\mathrm{NO}_{2}+\mathrm{NO}_{3}$ concentrations accompanied by a reduced total GSH content in the liver tissue homogenates 15 days after CPZ administration indicate that nitrosative stress associated with antioxidative defense system damage is present in this kind of liver damage (Table 2). The treatment with AGM leads to decreased $\mathrm{NO}_{2}+\mathrm{NO}_{3}$ concentrations compared to control group, which could be explained by protective effect of AGM on the mechanism of secondary inflammation (30).

The liver is an important source of GSH to the other peripheral tissues, so the intensive metabolism of xenobiotics in this organ could lead to GSH reduction and decline in GSH concentration in other peripheral tissues $(31,32)$. Glutathione neutralizes ROS within cells directly or through cycle glutathione
peroxidase/GSH (33). Significant reductions in total GSH concentration 15 days after subacute $\mathrm{CPZ}$ administration in the liver compared to the controls is consistent with the results of the research groups from other laboratories $(3,4)$.

Catalase can protect living organisms from oxidative damage by the removal of partially reduced oxygen species (34). The highest activity of CAT is present in the liver. One group of authors showed that $\mathrm{CPZ}$ administration in rats affected the activity of antioxidant enzymes (SOD and CAT) in liver tissue (35). At a dose-dependent manner CPZ leads to structural changes and modifications of membrane permeability of endothelial cells, which affects hemodynamic resistance vessels in vivo (36). Also, CPZ has prooxidant effects and acts through the operation of its metabolites, which are involved in the formation of $\mathrm{H}_{2} \mathrm{O}_{2}$ by the process of autoxidation (37). In addition to the protective effects against other oxygen radicals $\left(\mathrm{OH} \bullet\right.$ or $\left.\mathrm{O}_{2}{ }^{\bullet}\right), \mathrm{CPZ}$ is not involved in the removal of $\mathrm{H}_{2} \mathrm{O}_{2}$ (35). Fifteen days of $\mathrm{CPZ}$ application led to the decreased CAT activity in the liver compared to the control group (Table 2). This result could direct toward the mechanism of activation of hepatic stellate cells and Kupffer cells' proinflammatory response, which is involved in the development of inflammation and fibrosis (38). In our study, 15 days after subacute CPZ application, there was no difference in positivity of ED1 cells compared to the CPZ+AGM, as well as AGM group of animals on tissue sections of the rat liver. On the basis of the electrophoretic profiles of the ED1 molecules in the liver, we found clear differences in the level of expression of the protein, which were the most pronounced in the control group compared to all other groups 15 days after the treatment (Figure 1).

One explanation for the reduced antioxidant capacity and reduced CAT activity in the liver of rats after subacute $\mathrm{CPZ}$ application could be an increased CYP2E1 activity in the liver, which leads to the inactivation of CAT during poisoning (39). The treatment with $\mathrm{CPZ}+\mathrm{AGM}$ after 15 days leads to an increase in CAT activity as compared to the CPZgroup of animals (Table 2).

The results of this study firstly indicate that treatment with AGM accomplished a protective role against harmful CPZ poisoning. Thus, our findings provide useful information about AGM, which significantly supressed the oxidative and nitrosative stress parameters and restores antioxidant defense in the rat liver. 


\section{Acknowledgments}

This work was supported by the Military Medical Academy, Project No. МФВМА/6/15-17 and by the Ministry of Education, Science and Technological Development of the Republic of Serbia, Project No. III41018 funded. No conflict of interest exists for any of the authors of this article.

\section{References}

1. Balijepalli S, Kenchappa RS, Boyd MR et al. Protein thiol oxidation by haloperidol results in inhibition of mitochondrial complex I in brain regions: comparison with atypical antipsychotics. Neurochem Int 2001; 38: 425-35. http://dx.doi.org/10.1016/S0197-0186(00)00108-X

2. Parikh V, Khan MM, Mahadik SP et al. Differential effects of antipsychotics on expression of antioxidant enzymes and membrane lipid peroxidation in rat brain. J Psychiatr Res 2003; 37: 43-51. http://dx.doi.org/10.1016/S0022-3956(02)00048-1

3. Naidu PS, Singh A, Kulkarni SK. Carvedilol attenuates neuroleptic-induced orofacial dyskinesia: possible antioxidant mechanisms. $\mathrm{Br}$ J Pharmacol 2002; 136: 193-200.

http://dx.doi.org/10.1038/sj.bjp.0704717

4. Sulaiman A, Al-Shawi N, Jwaied A et al. Protective effect of melatonin against chlorpromazine-induced liver disease in rats. Saudi Med J 2006; 27: 1477-82.

5. Tukov FF, Maddox JF, Amacher DE et al. Modeling inflammation-drug interactions in vitro: a rat Kupffer cell-hepatocyte coculture system. Toxicol In Vitro 2006; 20(8): 1488-99.

http://dx.doi.org/10.1016/j.tiv.2006.04.005

6. Hassan HA, Yousef MI. Ameliorating effect of chicory (Cichorium intybus L.)-supplemented diet against nitrosamine precursors-induced liver injury and oxidative stress in male rats. Food Chem Toxicol 2010; 48: 2163-9. http://dx.doi.org/10.1016/j.fct.2010.05.023

7. Stankovic MN, Mladenovic D, Ninkovic M et al. The effects of $\alpha$-lipoic acid on liver oxidative stress and free fatty acid composition in methionine-choline deficient diet-induced NAFLD. J Med Food 2014; 17: 254-61. http://dx.doi.org/10.1089/jmf.2013.0111

8. Maslak E, Zabielski $\mathrm{P}$, Kochan $\mathrm{K}$ et al. The liverselective NO donor, V-PYRRO/NO, protects against liver steatosis and improves postprandial glucose tolerance in mice fed high fat diet. Biochem Pharmacol 2015; 93: 389-400.

http://dx.doi.org/10.1016/j.bcp.2014.12.004

9. Sharipov RR, Kotsiuruba AV, Kop"iak BS et al. Induction of nitrosative stress in mitochondria of rats hearts in experimental ischemia-reperfusion of the brain and its correction by ecdysterone. Fiziol Zh 2014; 60: 3-13.

10. Akyol O, Herken $\mathrm{H}, \mathrm{Uz} \mathrm{E}$ et al. The indices of endogenous oxidative and antioxidative processes in plasma from schizophrenic patients. The possible role of oxidant/antioxidant imbalance. Prog Neuropsychopharmacol Biol Psychiatry 2002; 26: 995-1005.

http://dx.doi.org/10.1016/S0278-5846(02)00220-8

11. Dejanovic B, Stevanovic I, Ninkovic M. et al. Protective effect of agmatine in acute chlorpromazine hepatotoxicity in rats. Acta Vet Brno 2014; 83: 305-12.

http://dx.doi.org/10.2754/avb201483040305

12. Ostojic JN, Mladenovic D, Ninkovic M et al. The effects of cold-induced stress on liver oxidative injury during binge drinking. Hum Exp Toxicol 2012; 31: 387-96.

http://dx.doi.org/10.1177/0960327111433899

13. Regunathan S, Youngson C, Raasch W et al. Imidazoline receptors and agmatine in blood vessels: a novel system inhibiting vascular smooth muscle proliferation. J Pharmacol Exp Ther 1996; 276: 1272-82.

14. Bhutada A, Ismail-Beigi F. Serum and growth factor induction of $\mathrm{Na}(+)-\mathrm{K}(+)$-ATPase subunit 
mRNAs in Clone 9 cells: role of protein kinase C. Am J Physiol 1991; 261: C699-707.

15. Li X, Fan X, Zheng ZH et al. Protective effects of agmatine on lipopolysaccharide-induced acute hepatic injury in mice. Zhonghua Wei Zhong Bing Ji Jiu Yi Xue 2013; 25: 720-4.

16. El-Agamy DS, Makled MN, Gamil NM. Protective effects of agmatine against Dgalactosamine and lipopolysaccharide-induced fulminant hepatic failure in mice. Inflammopharmacology 2014; 22: 187-94. http://dx.doi.org/10.1007/s10787-013-0188-2

17. Heitzman RJ. Veterinary drug residues. Commission of the European Communities, 2rd ed., 1994.

18. Gurd JW, Jones LR, Mahler HR et al. Isolation and partial characterization of rat brain synaptic membrane. J Neurochem 1974; 22: 281-90. http://dx.doi.org/10.1111/j.1471-4159.1974.tb11591.x

19. Lowry $\mathrm{OH}$, Rosenbrongh NJ, Farr AL et al. Protein measurement with the folin phenol reagent. J Biol Chem 1951; 193: 265-75.

20. Girotti M, Khan N, Mc Lellan B. Early measurement of systemic lipid peroxidation products in the plasma of major blunt trauma patients. J Trauma 1991; 31: 32-5. http://dx.doi.org/10.1097/00005373-199101000-00007

21. Navarro-Gonzalez JA, Garcia-Benayas C, Arenas J. Semiautomated measurement of nitrate in biological fluids. Clin Chem 1998; 44: 679-81.

22. Anderson ME. The DTNB-GSSG reductase recycling assay for total glutathione $(\mathrm{GSH}+$ 1/2GSSG). In: Greenwald RA (ed), Tissue glutathione, Florida, CRC Press, 1986: 31723.

23. Góth L. A simple method for determination of serum catalase activity and revision of reference range. Clin Chim Acta 1991; 196: 143-51. http://dx.doi.org/10.1016/0009-8981(91)90067-M

24. Harry GJ, Schmitt TJ, Gong Z et al. Lead-induced alterations of glial fibrillary acidic protein (GFAP) in the developing rat brain. Toxicol Appl Pharmacol 1996; 139: 84-93.

http://dx.doi.org/10.1006/taap.1996.0145
25. Couée I, Tipton KF. The inhibition of glutamate dehydrogenase by some antipsychotic drugs. Biochem Pharmacol 1990; 39: 827-32. http://dx.doi.org/10.1016/0006-2952(90)90196-R

26. Dejanovic B, Stevanovic I, Ninkovic M et al. Agmatine protection against chlorpromazineinduced forebrain cortex injury in rats. J Vet Sci 2015.

27. Di Ciero Miranda M, de Bruin VM, Vale MR et al. Lipid peroxidation and nitrite plus nitrate levels in brain tissue from patients with AD. Gerontology 2000; 46: 179-84. http://dx.doi.org/10.1159/000022156

28. Cardillo S, Iuliis AD, Battaglia V, Toninello A, Stevanato R, Vianello F. Novel copper amine oxidase activity from rat liver mitochondria matrix. Arch Biochem Biophys 2009; 485(2): 97101.

http://dx.doi.org/10.1016/j.abb.2009.03.006

29. Agostinelli E, Marques MPM, Calheiros R. Polyamines: fundamental characters in chemistry and biology. Amino Acids 2010; 38: 393-403. http://dx.doi.org/10.1007/s00726-009-0396-7

30. Lores-Arnaiz S, D'Amico G, Czerniczyniec A et al. Brain mitochondrial nitric oxide synthase: in vitro and in vivo inhibition by chlorpromazine. Arch Biochem Biophys 2004; 430: 170-7. http://dx.doi.org/10.1016/j.abb.2004.07.012

31. Lilic A, Dencic S, Pavlovic SZ et al. Activity of antioxidative defense enzymes in the blood of patients with liver echinococcosis. Vojnosanit Pregl 2007; 64: 235-40.

http://dx.doi.org/10.2298/VSP0704235L

32. Bannai $\mathrm{S}$, Sato $\mathrm{H}$, Ishii $\mathrm{T}$ et al. Enhancement of glutathione levels in mouse peritoneal macrophages by sodium arsenite, cadmium chloride and glucose/glucose oxidase. Biochim Biophys Acta 1991; 1092: 175-9. http://dx.doi.org/10.1016/0167-4889(91)90153-O

33. Lopert P, Patel M. Brain mitochondria from DJ-1 knockout mice show increased respirationdependent hydrogen peroxide consumption. Redox Biol 2014; 2: 667-72.

http://dx.doi.org/10.1016/j.redox.2014.04.010 
34. Li T, Zhou $\mathrm{Q}$, Zhang $\mathrm{N}$ et al. Toxic effects of chlorpromazine on Carassius auratus and its oxidative stress. J Environ Sci Health B 2008; 43: 638-43.

http://dx.doi.org/10.1080/03601230802352674

35. Can B, Demirci A, Uysal YD et al. Contradictory effects of chlorpromazine on endothelial cells in a rat model of endotoxic shock in association with its actions on serum TNF-alpha levels and antioxidant enzyme activities. Pharmacol Res 2003; 48: 223-30.

http://dx.doi.org/10.1016/S1043-6618(03)00093-8

36. Yabuki M, Tani N, Yoshioka $\mathrm{T}$ et al. Local thrombus formation in the site of intravenous injection of chlorpromazine: possible colloidosmotic lysis of the local endothelial cells. Biol Pharm Bull 2000; 23: 957-61.

http://dx.doi.org/10.1248/bpb.23.957
37. Kelder PP, Fischer MJ, de Mol NJ et al. Oxidation of chlorpromazine by methemoglobin in the presence of hydrogen peroxide. Formation of chlorpromazine radical cation and its covalent binding to methemoglobin. Arch Biochem Biophys 1991; 284: 313-9.

http://dx.doi.org/10.1016/0003-9861(91)90301-X

38. Koek GH, Liedorp PR, Bast A. The role of oxidative stress in non-alcoholic steatohepatitis. Clin Chim Acta 2011; 412: 1297-305. http://dx.doi.org/10.1016/j.cca.2011.04.013

39. Qi XM, Miao LL, Cai $Y$ et al. ROS generated by CYP450, especially CYP2E1, mediate mitochondrial dysfunction induced by tetrandrine in rat hepatocytes. Acta Pharmacol Sin 2013; 34: 1229-36.

http://dx.doi.org/10.1038/aps.2013.62 


\title{
Zaštitna uloga agmatina kod toksičnih efekata izazvanih hlorpromazinom $\mathbf{u}$ jetri Wistar pacova
}

\author{
Bratislav Dejanović ${ }^{1}$, Ivana Stevanović2, Milica Ninković', \\ Ivana Stojanović ${ }^{3}$, Irena Lavrnja ${ }^{4}$, Tatjana Radičević ${ }^{5}$ \\ ${ }^{1}$ Vojnomedicinski centar "Karaburma", Beograd, Srbija \\ ${ }^{2}$ Institut za medicinska istraživanja, Vojno medicinska akademija, Beograd, Srbija \\ ${ }^{3}$ Univerzitet u Nišu, Medicinski fakultet, Institut za biohemiju, Niš, Srbija \\ "Institut za biološka istraživanja "Siniša Stanković", Beograd, Srbija \\ ${ }^{5}$ Institut za higijenu i tehnologiju Mesa, Beograd, Srbija
}

\section{SAŽETAK}

Metabolički putevi oštećenja izazvani hlorpromazinom (CPZ) ispitivani su praćenjem markera oksidativnog/nitrozativnog stresa. Cilj studije bio je ispitati hipotezu da li agmatin (AGM) smanjuje oksidativni/nitrozativni stres u jetri Wistar pacova 15 dana posle davanja CPZ. Sve supstance aplikovane su intraperitonealno (i.p.) uzastopno 15 dana. Životinje su podeljene u četiri grupe: kontrolna (C, 0,9 \% fiziološki rastvor), CPZ (CPZ, 38,7 mg/kg TM), CPZ+AGM (AGM, $75 \mathrm{mg} / \mathrm{kg}$ TM odmah nakon CPZ, 38,7 $\mathrm{mg} / \mathrm{kg}$ TM i.p.) i AGM (AGM, $75 \mathrm{mg} / \mathrm{kg}$ TM).

Pacovi su žrtvovani dekapitacijom 15 dana nakon tretmana. Koncentracija CPZ je u CPZ grupi značajno povećana u poređenju sa kontrolnim vrednostima $(p<0,01)$, dok tretman AGM-om dovodi do značajnog smanjenja koncentracije CPZ u CPZ+AGM (p<0,05) i AGM grupi $(\mathrm{p}<0,01)$. Aplikacija CPZ zdravim životinjama ne dovodi do promene koncentracije TBARS u jetri pacova u poređenju sa kontrolom, međutim, tretman AGM-om smanjuje koncentraciju ovog parametra u poređenju sa CPZ grupom (p<0,05). U homogenatima jetre $\mathrm{CPZ}$ grupe, koncentracija nitrita i nitrata je povećana u poređenju sa kontrolom $(p<0,001)$ i tretman AGM-om smanjuje ovaj parametar u CPZ grupi ( $<<0,05)$, kao i u AGM grupi (p<0,001). Kod CPZ pacova smanjena je koncentracija glutationa, kao i aktivnost katalaze u poređenju sa $\mathrm{C}$ vrednostima (u svakoj grupi p<0,01), dok tretman AGM-om povećava aktivnost katalaze u poređenju sa CPZ životinjama (u svakoj grupi $p<0,05$ ). Western blot analiza prati biohemijske nalaze u svim grupama. Naši rezultati su pokazali da AGM smanjuje parametre oksidativnog/nitrozativnog stresa i oporavlja antioksidativni kapacitet $\mathbf{u}$ jetri pacova.

Ključne reči: agmatin, antioksidativna odbrana, hlorpromazin, jetra, oksidativni stres 